\title{
Financing Pattern and Utilization of Fixed Assets - A Study
}

\author{
Pradip Kumar Das ${ }^{1}$ \\ ${ }^{1}$ Commerce Unit, Jagannath Kishore College, Purulia (West Bengal), Affiliation under Sidho-Kanho-Birsha \\ University, Purulia, India \\ Correspondence: Dr. Pradip Kumar Das, Associate Professor \& Teacher-in-charge, Commerce Unit, Jagannath \\ Kishore College, Purulia (West Bengal), Affiliation under Sidho-Kanho-Birsha University, Purulia, India. Tel: \\ 91-3252-229922 \& 91-94-75-815209.
}

Received: April 24, 2017

Accepted: May 9, 2017

Online Published: June 5, 2017

doi:10.20849/ajsss.v2i2.159

URL: https://doi.org/10.20849/ajsss.v2i2.159

\begin{abstract}
Fixed assets are the assets of permanent nature used in the operation of a business. These assets are earning assets and provide the basis for the firm's earning power and value. Due attention must be given to the management of fixed assets as they represent sizable outlay and involve the long-term financial commitment. A systematic blending of current and fixed assets into a profitable combination is a challenging task to the financial management. An analysis on the financing pattern and utilization of fixed assets is, therefore, vital for the management of a business enterprise.

The financing pattern and utilization of fixed assets of Tata Steel Ltd., the selected company have been studied with the help of several statistical measures during the period from 2011-12 to 2015-16.

The study reveals the sufficiency of owners' funds to finance fixed assets requirements and that the company had also enough long-term funds to finance the entire fixed assets as well as part of current assets. The pace of expansion in gross block on sales was not impressive in the years of study. Apart from this, slow increase in the indices of depreciation points out that overall provision for depreciation was moderate in the company under reference.
\end{abstract}

Keywords: financial pattern, utilization of fixed assets, depreciation, financial commitment, financial management

\section{Introduction}

An important problem confronting the top level management of a business enterprise is to decide whether the firm should invest funds in fixed assets or not. Fixed assets are the assets of permanent nature and are used in the normal operations of a business undertaking. In the words of Finny, "Fixed assets are the assets of a relatively permanent nature used in the operation of a business and which are not intended for sale" (Finny, 1968). They are necessary for manufacturing firms, since production would be impossible without them (Gitman, 1982). Fixed assets can also be often referred to as earning assets and usually provide the basis for the firm's earning power and value. The level of fixed assets is dependent on the nature of the firm's production process. Essentially, fixed assets such as land and buildings, plant and machinery are incidental to production used over a considerable period of time, and are not meant for sale (Chowdhury, 1964). The amount invested in fixed assets is not realized at once from the total sales during an accounting year (Kulshrestha, 1972). The cost of fixed assets are regained in the form of depreciation, which is usually charged as an expense against the revenues generated through the use of these assets in the production process. Thus, these assets which are consumed slowly in the production process are replaced periodically. Hence, a great deal of attention must be given to the management of fixed assets investment in a firm since they delineate sizable outlays and live longer than a year and involve a long-term financial commitment. A systematic blending of current and fixed assets into a profitable combination is a challenging task for the financial management (Kulshrestha, 1972). The analysis of fixed assets is also very important from the investors' point of view, since they are more concerned with long-term assets. It is in this context that a modest effort has been made in this paper to measure and evaluate the financing pattern and utilization of fixed assets in Tata Steel Ltd., India's largest steel company.

\section{Objective of Study}

The basic objectives of the study are: 
1. To evaluate the financing pattern of fixed assets.

2. To test the efficiency of fixed assets utilization.

3. To assess the impact of fixed assets on sales and operating profits.

4. To examine the sufficiency of provision for depreciation.

\section{Data and Methodology}

The researcher being an external analyst has to depend mainly upon the secondary data for the analysis of the financing pattern and utilization of fixed assets of the selected company i.e. Tata Steel Ltd. Hence, the data and information required for the study have been collected mostly from the annual reports, accounting records of the company etc. for the period from 2011-12 to 2015-16. This moderately lengthy period of five years has been adopted for arriving at meaningful and purposeful inferences. A few information has also been collected from the website of the company. Though there was found apathy or indifference on the part of the executives in supplying information, the researcher could overcome the same through moral persuasion and intensive pestering. It was made clear to them that the information so collected will be exclusively used for academic purpose and proper secrecy will be maintained. Editing, classification and tabulation of the financial data collected from the above mentioned sources have been done as per the requirement of the study.

The figures collected from the sources have been rounded off to two decimals. The data available have been translated into a pre-designed structure format so that a significant interpretation could be made.

With a view to knowing the financing pattern and utilization of fixed assets of the selected company, the commonly used ratios i.e. fixed assets to net worth ratio, fixed assets to long-term funds ratio, fixed assets turnover ratio and indices of fixed assets (gross block), sales and operating profit and also indices of gross block and depreciation have been computed and analyzed.

The study has been presented in four sections. Section-I relates to the profile of Tata Steel Ltd., the selected company. Section-II presents the financing pattern of fixed assets of the company. In the Section-III, utilization of fixed assets of the selected company has been tested. Finally, the Section-IV contains conclusions of the results drawn during the course of study.

\section{Section-I}

\subsection{A Brief Profile of Tata Steel Ltd.}

Tata Steel Ltd., established in 1907, the flagship company of the Tata group is the integrated steel plant in Asia and is now the world's second most geographically steel producer and a Fortune 500 company. Tata Steel Ltd., backed by more than 100 glorious years of experience in steel making is the world's 6th largest steel company with an existing annual steel production capacity of more than 30 Million Tonnes Per Annum (MTPA). Tata Steel Ltd. has a global presence in over 50 developed European and fast growing Asian markets, with manufacturing units in 26 countries. The iron ore mines and collieris in India give the company a distinct advantage in raw material sourcing. This company, the first integrated steel company in the world was awarded the Deming Application Prize 2008 for excellence in Total Quality Management. Besides this, Tata Steel Ltd. won several national and international prestigious awards in different times.

\section{Section-II}

\subsection{Financing Pattern of Fixed Assets}

"The investment in fixed assets involves commitment of funds for longer period into the future and usually is difficult and costly to reverse often as they are in large increments" (Hunt, 1965). Fixed assets portray permanent investment of funds and therefore, they have to be primarily financed by the owners' funds or proprietors' funds. Usually, funds provided by the owners or proprietors should be adequate not only to finance the entire requirements of fixed assets but also some of the current assets which are relatively permanent in nature. Furthermore, if required, fixed assets are to be preferably financed through long-term debt. It implies that at any cost, short-term funds should not be used to finance fixed assets. With a view to studying the financing pattern of fixed assets in the selected company, two relevant and important ratios viz. (i) fixed assets to net worth and (ii) fixed assets to long-term funds have been computed.

\subsubsection{Fixed Assets to Net Worth Ratio}

This ratio specifies largely the extent to which fixed assets are being financed by equity interests. In other words, this ratio explains the relationship between net fixed assets and tangible net worth viz. preference share capital, equity share capital inclusive of retained earnings minus intangibles. In the words of Roy Chowdhury, "The ratio 
of fixed assets to owners' funds indicates the relationship between net worth and investment in fixed assets (i.e. gross block less depreciation)" (Roy Chowdhury, 1970). J.J. Bogen observes, "The ratio measures the proportion of contributed capital that has been invested in fixed property" (Bogen, 1957). This ratio is an important tool for judging the margin of safety for long-term creditors. A ratio exceeding unity or $100 \%$ would mean that a portion of fixed assets is being financed by long-term debt capital i.e. creditors' funds. But the ratio less than unity or $100 \%$ reflects that the owners' funds are adequate to cover not only fixed assets but also a part of current assets; it may also mean the non-existence of any long-term fixed interest bearing finance in the firm. On the other hand, if the ratio is equal to $100 \%$, it means all fixed assets are being supported by proprietors' equity or net worth. The latter two situations indicate the security and firmness of the firm from the point of view of shareholders. But normally the ratio may be more than $100 \%$ because efficient financial management claims that there should be some fixed interest bearing capital in the firm's financial structure. The lesser the ratio, the greater is the margin of safety for long-term creditors. In other words, the higher the ratio, the less would be the protection available to creditors and it is a sign of weakness from the point of view of a firm's long-term solvency. Net worth less than fixed assets implies that the loan funds are used to finance a part of the fixed assets and when the amount of ownership funds exceeds the value of fixed assets, a part of the net working capital is provided by the shareholders. The yardstick for this measure is $65 \%$ or 0.65 time for industrial undertakings (Weston, 1972). It implies that $65 \%$ of ownership funds are to be used for acquiring fixed assets and the remaining for financing current assets. Ownership funds are sufficient for acquiring fully the fixed assets and that of $35 \%$ of these funds must be available for financing current assets.

Table-I evidences the ratio of fixed assets to net worth in the selected company. It is observed from the table that the company had used shareholders' funds to the extent of 0.21 time, 0.43 time, 0.38 time, 0.37 time and 0.35 time in the years 2011-12, 2012-13, 2013-14, 2014-15 and 2015-16 respectively to finance its fixed assets. Thus, this ratio had varied from 0.21 time in 2011-12 to 0.43 time in 2012-13. The ratios were always less than unity indicating adequacy of owner's funds to finance its fixed assets and a part of current assets throughout the period of study. The average of this ratio was 0.35 time during the period under study. The table shows that the ratio of fixed assets to net worth had increased from 2011-12 to 2015-16. The performance of the company selected for study can be compared to the standard norm of 0.65 time. The ratio was always much less than the standard norm of 65 percent from 2011-12 to 2015-16. On an average also, this ratio was below the standard ratio indicating use of shareholders' funds to the extent of $35 \%$ to finance its fixed assets.

Table 1. Selected Ratios in Tata Steel Ltd.

\begin{tabular}{lllllll}
\hline & \multicolumn{1}{l}{ Year } & & & & & $\bar{X}$ \\
\cline { 2 - 6 } Name of the Ratio & $2011-12$ & $2012-13$ & $2013-14$ & $2014-15$ & $2015-16$ & \\
\hline $\begin{array}{l}\text { Fixed Assets to Net Worth Ratio } \\
\text { (in time) }\end{array}$ & 0.21 & 0.43 & 0.38 & 0.37 & 0.35 & 0.35 \\
\hline $\begin{array}{l}\text { Fixed Assets to Long-term Funds } \\
\text { Ratio (in time) }\end{array}$ & 0.46 & 0.89 & 0.84 & 0.84 & 0.87 & 0.78 \\
\hline $\begin{array}{l}\text { Fixed Assets Turnover Ratio (in } \\
\text { time) }\end{array}$ & 1.48 & 1.01 & 1.07 & 1.00 & 0.88 & 1.09 \\
\hline
\end{tabular}

Source: Annual Reports and Accounts; Results Computed.

It is observed from Table-I that the company had employed its own funds to finance fixed assets as the percentage of fixed assets to net worth was less than $100 \%$ in all the years under review. It also indicates that the company had not borrowed funds to finance fixed assets; rather, the entire fixed assets had been financed from ownership funds. In other words, the shareholders' funds had also been used to finance permanent current assets of the company selected for study. It reflects that the financing pattern of fixed assets was built on well established financial policies, principles and methods; it was not merely a matter or decision of own convenience. Though, the ratio of fixed assets to net worth had increased to some extent but still it seems sound financial position and might be better in the years to come. It means adequacy of shareholders' funds in financing fixed assets in all the years of study. 


\subsubsection{Fixed Assets to Long-Term Funds Ratio}

Fixed assets are obtained by a business for permanent use and as such usually represent more or less permanent investment. Normally, fixed assets are financed from long-term funds composing the proprietors' funds and long-term borrowed funds. Fixed assets should usually be financed by proprietors' funds. However, if it is required to finance the fixed assets under a few particular and peculiar conditions from borrowed sources, only long-term debt should be more desirable. The total long-term funds should be sufficient enough to finance fixed assets departing a part of these funds to finance permanent working capital requirements. Otherwise, it would result in financial embarrassment.

Viewed in this context, fixed assets to long-term funds ratio has been applied to study the financing pattern of fixed assets. This ratio is related to fixed assets with long-term funds. The long-term funds for this purpose consist of owner's funds (as represented by tangible net worth) and long-term borrowed funds. This ratio supplies information about the sufficiency of long-term funds in financing the fixed assets or the extent of fixed assets financed by current debt due to deficiency of long-term funds.

Ideally, this ratio should not exceed unity. Ratio less than unity means that the long-term funds are more than the fixed assets and that they are used for the purposes of other than the long-term assets i.e. for financing working capital (Hingorani, 1977). Hence, this ratio is closely related to the concept of net working capital. The difference between current assets and current liabilities is commonly known as net working capital. Excess of current assets over current liabilities implies that excess of current assets is being financed through long-term funds. Hence, the long-term funds must cover some current assets requirements too and then only appearance of working capital is to be considered as the excess of current assets over current liabilities. Inadequacy of long-term funds to finance the entire fixed assets results in working capital deficit. In such a situation, a company has to face a lot of financial crisis to fill in the gap of working capital. The ratio is calculated by dividing net fixed assets with the long-term funds.

It is evident from Table-I that this ratio was 0.46 time in 2011-12, 0.89 time in 2012-13, 0.84 time in 2013-14, 0.84 time in 2014-15 and 0.87 time in 2015-16. Thus, the ratio had varied from 0.46 time in 2011-12 to 0.89 time in 2012-13 during the period of study. This ratio shows less thin unity for the entire period indicating the adequacy of long-term funds to finance the fixed assets. The share of fixed assets on an average had constituted 0.78 time of long-term funds in the company selected for study. It also reflects that after meeting the entire fixed assets requirements, the company was able to provide on an average 0.22 time of long-term funds to finance the net working capital.

The situation appears to be good, despite variations in the ratio throughout the study period under reference. An analysis of the ratio points out that the company had sufficient long-term funds to finance the fixed assets as well as part of the current assets, as its average ratio worked out to below unity. But the ratios had reported fluctuations and the ratios over the years show utilization of long-term funds to meet the needs of current assets after encountering the fixed assets need of the company.

The surplus long-term funds enabled the company to strengthen its working capital financing. But at the same time a margin is left for long-term funds. Even then there was no need for any anxiety as this ratio was less than unity.

Thus, the study shows that the financing pattern of fixed assets through long-term funds was satisfactory in the company under reference.

\section{Section-III}

\subsection{Utilization of Fixed Assets}

Usually, sales vindicate the quantum of fixed assets employed in an enterprise. The effective utilization of fixed assets in an enterprise is gauged by the fixed assets turnover ratio. One of the most potent tools employed to evaluate the effectiveness of the utilization of fixed assets is assets turnover (Srivastava, 1979). The turnover of fixed assets denotes their contribution to sales. Hence, it is an important component of overall profitability. Westiwick also suggests the application of fixed assets turnover ratio to measure the utilization of fixed assets (Westiwick, 1973). Turnover means the number of times an asset flows through a firm's operation into sales. The turnover of fixed assets investment is defined as the relationship between the volume of business done and the amount of capital tied-up in fixed property investments (Bogen, 1957). This ratio is calculated by dividing net sales with net fixed assets.

The ratio indicates the rate at which different assets such as land \& building, plant \& machinery, furniture \& fixture, vehicle etc. are turned over. It measures the competency with which a firm is utilizing its investment in 
fixed assets. The ratio shows the adequacy of sales in relation to the investment in fixed assets. A moderately high fixed assets turnover ratio indicates the effective utilization of fixed assets in generating sales while a law ratio, indicates idle capacity and inefficient management and utilization of fixed assets. An excessive high ratio is also an indication of overtrading on assets. It also shows that a corporation has an excessive investment in fixed assets in comparison to the volume of sales. Further, in short-run fixed assets turnover ratio can be good indicator of efficiency because a firm cannot adjust its fixed assets for short-term market fluctuations.

The fixed assets turnover ratio of the selected company has been catalogued in Table-I. The table also gives an idea of turnover of fixed assets employed by the company under study. It had varied from 0.88 time in 2015-16 to 1.48 times in 2011-12. It was mainly on account of fluctuations in the amount of fixed assets in the period under reference. The average of this ratio worked out to 1.09 times which infers that the company had earned rupees 1.09 for every rupee invested in fixed assets. The ratio had reached the peak level of 1.48 times in 2011-12 reflecting marketing efficiency and effective utilization of fixed assets by the company. The fixed assets turnover ratio in the company had registered a decrease from 1.48 times in 2011-12 to 0.88 time in 2015-16. This may be supported by the fact that the management of the company under study had an attempt to make good use of its fixed assets but did meet expected success.

\subsubsection{Impact of Fixed Assets (Gross Block) on Sales and Operating Profits}

The evaluation of the impact of fixed assets (gross) on sales and operating profits is yet another way of measuring the utility of fixed assets. Usually, the upward sales trend justifies the expansion of gross block. The expanding gross block too should have its impact upon sales as well as operating profits. If the trends of gross block and sales are increasing, it can be said that expansion of gross block is due to increase in sales, or sales have justified the need for expansion of fixed assets (gross). If the rate of growth in gross block is higher than that of the sales, it reflects excessive investment in gross block as well as it's under utilization. On the other hand, if the sales growth rate is higher than the rate of growth of gross block, it can be said that there is better utilization of gross block expansion. The increasing trend in operating profit along with the increase in gross block and sales is an indication of better operating efficiency and more profitable sales. If the operating profits show stagnant or a declining trend, the expansion of gross block may not be profitable though there is increase in volume of sales.

Table 2. Indices of Fixed Assets (Gross Block), Sales and Operating Profits in Tata Steel Ltd. (Base Year 2011-12 $=100)$

\begin{tabular}{llllll}
\hline Particulars & Year & & & \\
\cline { 2 - 6 } & $2011-12$ & $2012-13$ & $2013-14$ & $2014-15$ & $2015-16$ \\
\hline Gross Block & 100 & 164 & 169 & 181 & 190 \\
\hline Sales & 100 & 112 & 123 & 124 & 113 \\
\hline $\begin{array}{l}\text { Operating } \\
\text { Profit }\end{array}$ & 100 & 97 & 110 & 85 & 89 \\
\hline
\end{tabular}

Source: Annual Reports and Accounts; Results Computed

With a view to studying the trends in gross block, sales and operating profits, indices for these variables have been computed taking 2011-12 as the base year. Table-II depicts these trends along with operating profit for the study period from 2011-12 to 2015-16. It is observed that the sales growth rate was always less than that of rate of growth of gross block in the company. Although both gross block and sales had enjoyed an increase except sales in the last year, the rate of growth in gross block was comparatively sound than the rate of sales growth. This fact, therefore, evidences poor utilization of gross block expansion. The pace of expansion in gross block on sales was not impressive in the years of study. Hence, it may deduce that the excessive investment in gross block as compared to sales shows under utilization of gross block expansion.

The operating profit had shown fluctuations but it had decreased from 2011-12 to 2015-16 i.e. over the study period. The impact of expanded gross block and improved sales on operating profit had not shown consistency during the period of study. An observation of the company reveals the favorable as well as unfavorable impact of gross block on sales and profit. In spite of expanding investment in fixed assets (gross) and consequent improvement in sales, comparatively the profit in all the years of study in the company was poor and unstable. 
This might be due to escalating operating costs.

\subsubsection{Analysis of Depreciation Policy}

Depreciation policy, as a matter of fact, is of considerable importance to the financial manager because of its impact on profitability, its size in relation to total cost of operation, its effect on rate of return on investment and finally its relationship to replacement policy. Depreciation is a permanent, continuing and gradual shrinkage in the book value of fixed assets at a given rate as compared with its value at previous date. In fact, depreciation is the systematic allocation of the cost of capital equipment to the revenues (Henderson, 1984). In the words of Anthony and Reece, "Depreciation is a fraction of the cost of the fixed assets properly chargeable as an expense in each of the accounting periods in which the asset is used by the company. The accounting process for this gradual conversion of fixed assets to expense is called depreciation (Anthony, 1975). Actually, depreciation denotes the extent of realization of the money sunk in the fixed assets of the current year's revenues. In other words, it represents the extent of services received from fixed assets.

Physical assets may have productive uses for many years; but eventually they will wear or become obsolete and have little value. As depreciation is charged against revenues, it denotes revenues consumed. It is frequently contended that depreciation provides fund for replacement at the expiry of the productive life of an asset. Usually, depreciation is calculated either based on written down value method or straight-line method. The choice of the appropriate method of depreciation has important consequences for financial management.

In India, business enterprises calculate depreciation according to the provisions of the Indian Companies Act. The amount of depreciation is calculated on historical cost of the asset. Business firms make provision for depreciation on written down value method or straight-line method in accordance with specific sections of the Indian Companies Act. Indian Companies Act also contains revised rate of depreciation for different assets.

Tata Steel Ltd., the selected company provides depreciation on straight-line basis for fixed assets at the rates and in the manner prescribed in the Companies Act (Annual Reports, 2011-12 to 2015-16). An attempt has been made here to analyze the adequacy of depreciation provided in the company selected for study over the years.

\subsubsection{Adequacy of Depreciation (On Historical Cost Basis)}

An examination with regard to adequacy or otherwise of depreciation is done on historical cost basis. With this object in view, the trend of the depreciation is compared with the trend of gross block. As such index numbers are computed for the gross block and depreciation provision by taking 2011-12 as the base year. Movement in the same direction of both these factors indicates that sufficient provision for depreciation has been made. If the pace of increase in the indices of depreciation exceeds that of the gross block, it is a sign of liberal provision for depreciation. If the gross block shows an increasing trend while depreciation reports a decreasing trend, it indicates insufficient provision of depreciation (Kennedy, 1994). With a view to continuing in business, an enterprise should necessarily provide depreciation to replace its fixed assets as they wear out.

Table 3. Indices of Gross Block and Depreciation in Tata Steel Ltd.

\begin{tabular}{llllll}
\multicolumn{2}{l}{ (Base Year 2011-12 $=\mathbf{1 0 0})$} \\
\hline Particulars & Year & & & \\
\cline { 2 - 6 } & $2011-12$ & $2012-13$ & $2013-14$ & $2014-15$ & $2015-16$ \\
\hline Gross Block & 100 & 164 & 169 & 181 & 190 \\
\hline Depreciation & 100 & 113 & 127 & 145 & 160 \\
\hline
\end{tabular}

Source: Annual Reports and Accounts; Results Computed.

Table 3 presents the overall trend of indices of depreciation and gross block. The table reveals that the indices of gross block and depreciation were in upward direction. But the pace of increase in the indices of depreciation was less than the pace of increase in gross block evidencing moderate provision for depreciation in Tata Steel Ltd.

To conclude, overall provision for depreciation in Tata Steel Ltd., the selected company was found to be moderate. 


\section{Section- IV}

\subsection{Concluding Observation}

From the foregoing analysis, the study unfolds the following interesting features:

I. Owners' funds were sufficient to finance fixed assets requirement in the company under study.

II. The company had not borrowed funds to finance fixed assets rather the entire amount of fixed assets had been financed from ownership funds.

III. The company selected for study had sufficient long-term funds to finance the entire fixed assets as well as part of current assets. The situation appears to be reasonably good, despite variation in the ratio throughout the study period under reference.

IV. The study shows maximum utilization of long-term funds to meet the needs of net working capital after meeting the fixed assets requirements of the company.

V. A margin left for long-term funds enabled the company to strengthen its working capital financing.

VI. The fixed assets turnover ratio infers that the management of the selected company under study had an attempt to make good use of its fixed assets, but did not meet expected success.

VII.It is observed that gross block and sales had enjoyed an increase over the years under study; but, the rate of growth in gross block was comparatively high than the rate of sales growth. The pace of expansion in gross block on sales was not impressive in the years of study. Hence, it may be deduced that the excessive investment in gross block as compared to sales shows under utilization of gross block expansion.

VIII. An observation of the company reveals the favorable as well as unfavorable impact of gross block on sales and profit.

IX. The study reveals that the indices of gross block and depreciation were in upward direction; but slow increase in the indices of depreciation points out that overall provision for depreciation in the selected company was moderate.

\section{References}

Annual Reports. (from 2011-12 to 2015-16) of Tata Steel Ltd.

Anthony, R. N., \& Reece, J. S. (1975). Management Accounting - Text and Cases, Illinois: Richard D. Irwin, p. 198.

Bogen, J. J. (1957). Financial Hand Book. New Delhi: The Ronald Press, p. 253.

Bogen, J. J. Op. cit., pp. 751-752.

Chowdhury, S. B. (1964). Analysis of Company Financial Statements. Bombay: Asia Publishing House, p. 31.

Finny, H. A., \& Miller H. E. (1968). Principles of Accounting. New Delhi: Prentice Hall of India, p. 163.

Gitman, L. J. (1982). Principles of Management Finance. New York: Harper \& Row Publishers, p. 381.

Henderson, G. V., Gurry, J. R., Trennep Oh., \& James E. W. (1984). An Introduction to Financial Management. California: Addition - Wesley Publishing Company, p. 122.

Hingorani, N. L., \& Ramanathan, A. R. (1977). Management Accounting. New Delhi: Sultan Chand \& Sons, p. 115 .

Hunt, W., \& Donaldson, G. (1965). Business Finance - Text and Cases. Illinois: Richard D. Irwin, pp. 114-115.

Kennedy, R. D., \& McMullen, S. Y. (1994). Financial Statements: Forms, Analysis and Interpretation. Illinois: Richard D. Irwin Inc., p. 404.

Kulshrestha, N. K. (1972). Analysis of Financial Statements of Indian Paper Industry. Aligarh: Navman Publishing House, p. 133.

Kulshrestha, N. K. Op. cit., p. 134.

Roy Chowdhury, A. B. (1970). Analysis and Interpretation of Financial Statements. New Delhi: Orient Longmans, p. 24.

Srivastava, R. M. (1979). Financial Management. Meerut, India: Pragati Prakashan, p. 476.

Westiwick, C. A. (1973). Management: How to use Ratios. Epping Essex: Grower Press Ltd., p. 5.

Weston, J. F., \& Brigham, E. F. (1972). Managerial Finance. New York: Holt, Rinehart and Winston, Inc., p. 88. 


\section{Copyrights}

Copyright for this article is retained by the author(s), with first publication rights granted to the journal.

This is an open-access article distributed under the terms and conditions of the Creative Commons Attribution license (http://creativecommons.org/licenses/by/4.0/). 